\title{
Atopy in Kashmir-validation from a case control study with respect to $\lg E$ and Interleukin genes
}

\author{
Taha Ashraf Qurashi ${ }^{1}$, Aaliya Shah ${ }^{2 \dagger}$, Gulzar Ahmad Bhat ${ }^{1 \dagger}$, Mosin Saleem Khan ${ }^{1 \dagger}$, Roohi Rasool ${ }^{3}$ and \\ Syed Mudassar ${ }^{1 *}$
}

\begin{abstract}
Objectives: Increased levels of serum Immunoglobulin-E (IgE) and different genetic variants of cytokines are common biochemical manifestation in Allergy. The current study was aimed to study the association of IgE and different variants of Interleukin-4 (IL-4), and Interleukin-13 (IL-13) genes with different kind of allergies.

Methods: A pre-tested questionnaire was used to collect all the dietary, life style and clinical details by a trained staff. A blood sample of $2 \mathrm{ml}$ each was collected in coagulated and anti-coagulated vials. DNA and serum samples were extracted and stored until further use. Serum IgE were estimated by ELISA while as the genotypic analysis was done by PCR-RFLP methods.
\end{abstract}

Results: Statistically a significant difference of serum lgE levels were observed among cases and controls $(P<0.05)$. The observed significant difference of serum IgE levels were retained among subjects who also harboured variant genotypes of $I L-4$ and $I L-13$ genes $(P<0.05)$. Additionally, the above genetic variants significantly modified the risk of allergy when stratification was done based on various clinical characteristics.

Conclusion: Our study suggests that increased IgE levels and in association with variant forms of IL-4 and IL-13 genes are significantly associated with different types of allergies in study population.

Keywords: IgE, Interleukin gene variants, Atopy, Case control study, Kashmir

\section{Introduction}

Allergic disorders are considered an epidemic in the developed world with rising incidence rate in the developing countries as well [1-3]. These disorders though multi-etiological but none has been established as a causative factor individually until now. The increased prevalence associated with large differences between urban and rural regions, hints at environmental factors

\footnotetext{
*Correspondence: syed.mudassar@skims.ac.in

${ }^{\dagger}$ Aaliya Shah, Gulzar Ahmad Bhat and Mosin Saleem Khan have contributed equally as second authors

${ }^{1}$ Department of Clinical Biochemistry, Sher-I-Kashmir Institute of Medical Sciences, Srinagar 190011, India
}

Full list of author information is available at the end of the article but genetics play a key role independently as well as in combination by modifying environmental and life style exposures.

The condition that result due to exposure of body to environmental substances is characterized by raised serum Immunoglobulin-E (IgE) levels- a feature of allergic diseases. It results due to immune reaction to an antigen called an allergen, which is normally harmless $[4,5]$. Allergen-specific IgE- antibodies cause most allergic reactions. A number of atopy susceptibility interleukin genes have been identified which regulate the production of IgE [6, 7]. Genome wide Association studies have identified strong linkage of a region on chromosome 5q31-33 with atopic disorders in different 
populations [8-11]. Different interleukins (IL) like $I L-4$ and $I L-13$ genes been reported to regulate IgE synthesis and hence potentially involved in manifestation of allergic disorders [12-14]. The genetic polymorphisms in $I L-4$ and $I l-13$ genes are the most common genetic alteration in patients having atopic disorders. A number of studies regarding the different polymorphic variants of inflammatory genes and different allergic phenotypes are available [12, 14, 15]. Discovery of these genetic alterations has created the opportunity to develop novel clinical strategies for the management and treatment of these patients.

A number of studies regarding the different polymorphic variants of inflammatory markers and allergic phenotypes are available [12, 14, 15]. The hyperactive immune response in the form of increased levels of IgE and altered IL genetic variants as a common biochemical manifestation among allergic patients has been reported previously [16-20]. Considering, the above findings and possibility of higher incidences of allergies due tosuitable environmental settings for allergies in the form of fluffy seeds from poplar trees and blooms in Kashmir, we intend to identify the patients having different types of allergic disorders, elucidate their serum IgE levels, and find out any possible correlation with certain gene variants of $I l-4$ and $I L-13$.

\section{Materials and methods \\ Patients and controls}

A total of 528 subjects presented with different allergic symptoms attending Allergy Clinic, Sher-i-Kashmir Institute of Medical Sciences (SKIMS), Department of Dermatology, SKIMS Medical College and Department of Dermatology, Sheri Maharaja Hari Sing (SMHS) Hospital Srinagar were included in this study. A subject is diagnosed as "Atopic" if they have presence of any/ all of the phenotypes like; allergic rhinitis (AR), atopic dermatitis (AD), and bronchial asthma (BA) called as allergic triad. Persons with Atopy also have a tendency to have allergic conjunctivitis, food allergy and occupational allergy apart from the above phenotypes. Blood samples were collected from all 528 cases. Blood samples were also obtained from 610 no-atopic subjects from the Out Patients Departments of above Departments. A written pre-informed consent was obtained from all cases and controls. The study was approved by the Institutional Ethical Clearance Committee of SKIMS, Srinagar vide order No. SIMS 1 131/IEC-SKIMS/2016-133.

\section{Case control selection and data collection}

The subject selection was based on the following.

\section{Inclusion criteria}

All individuals with $\mathrm{AD}, \mathrm{AR}$, and $\mathrm{BA}$ were included in the study as cases. Patients with allergic conjunctivitis, food allergy, and occupational allergy were also included in the study as cases, in addition to $\mathrm{AD}$, $A R$, and BA. Those who did not have any of the aforementioned allergic problems served as control subjects.

\section{Exclusion criteria}

Individuals with any genetic disorder, malignancy, chronic obstructive pulmonary disease and acute chronic obstructive pulmonary disease were excluded from the study. Individuals on beta-blockers and/or with any sort of autoimmune disorder are not eligible for immunotherapy, so they were also excluded from the study.

\section{Data collection}

Detailed information on age, sex, place of residence, ethnicity, religion, education, dietary data and other potential confounding factors of interest was collected using a questionnaire pre-designed for the study population. Detailed information on lifelong history of use of several tobacco products was obtained. Information on family history of any allergic disorder was obtained from all the participants. To assess the socio-economic status (SES) of the subjects, information on potential parameters of SES was obtained including education level (highest level attained), monthly income (INR), house type and ownership of several household appliances. Similarly, the information regarding, second hand smoking was also acquired from all the recruited subjects.

\section{Specimen}

After obtaining verbal and written consent from all cases and controls, at least $4 \mathrm{ml}$ of blood sample was collected from both cases and controls in EDTA and red top vials. Serum and whole blood sample containing vials were stored at $-20{ }^{\circ} \mathrm{C}$ until further use. Serum samples were used to measure the IL-4 and IL-13 levels by Enzyme linked Immunosorbent assay (ELISA). Whole blood samples were used for DNA extraction followed by polymorphic analysis of $I L-4, I L-$ 13 and STAT6 genes.

\section{Skin prick test (SPT)}

European Academy of Allergy and Clinical Immunology (EAACI) recommendations were used to perform SPT. Saline was used as negative control and histamine $10 \mathrm{mg} / \mathrm{ml}$ was used as positive control. Antihistamines 
were discontinued before skin testing according to published guidelines. Skin tests were considered positive if at least one allergen elicited a wheal reaction of more than $3 \mathrm{~mm}$ of diameter after subtraction of the negative control. Patients were considered atopic if at least they had one positive skin test result.

\section{Estimation of Biochemical and Hematological markers}

Serum samples were used for estimation of IgE and Vitamin D levels on Access 2 Immunoassay System (Beckman Coulter, Inc., USA) using CLIA technique. Whole blood samples were used for estimation of eosinophil count on Sysmex XP-300 ${ }^{\mathrm{TM}}$ Automated Hematology Analyzer (Sysmex America, Inc., USA) and Erythrocyte sedimentation rate (ESR) using Westergren' method. IgE level of $>180 \mathrm{IU} / \mathrm{ml}$ was taken as "Elevated". In case of Vitamin D levels, $<20 \mathrm{ng} / \mathrm{ml}$ was considered as "Deficient", $20-30 \mathrm{ng} / \mathrm{ml}$ as "Insufficient", 31-100 ng/ $\mathrm{ml}$ as "Sufficient" and $>100 \mathrm{ng} / \mathrm{ml}$ as "Upper safety limit". Relative eosinophil count $>6 \%$ of peripheral blood was considered as "Elevated". ESR of $>15 \mathrm{~mm} / \mathrm{hr}$ in males; $>20 \mathrm{~mm} / \mathrm{hr}$ in females; $>10 \mathrm{~mm} / \mathrm{hr}$ in children was taken as "Elevated".

\section{Pulmonary function test}

A spirometry test was performed to access the pulmonary function of each enrolled patient. Forced expiratory volume in $1^{\mathrm{ST}}$ second (FEV1) is a very good and direct indicator of lung function. FEV1 of less than $80 \%$ was considered as "Abnormal". Post Broncho dilatory Response (PBD) is change in FEV1 after 15-20 min of use of Bronchodilator (Salbutamol; $200 \mu \mathrm{g}$ ). PBD of " $>200 \mathrm{ml}$ and $>12 \%$ " is significant for a Reversible Lung disease like Asthma. If PBD is " $<200 \mathrm{ml}$ and $<12 \%$ " the reversibility is not significant as we see in Chronic Pulmonary Obstructive Disease (COPD) and Asthma COPD Overlap Syndrome (ACOPD). Forced vital capacity (FVC) is an indicator of Restrictive lung disease hence not included in our analysis.

\section{ELISA principle and method}

The ELISA was done as described previously [21]. Briefly, a capture antibody highly specific for IL- 4 and IL- 13 were coated to the wells of the microtiter strip plate. Binding of IL-4 and IL-13 in samples and known standards to the capture antibodies was completed and any excess unbound analyte was removed. During the next incubation period the binding of the biotinylated antiIL-4 and IL-13 secondary antibody to the analyte occurs. Any excess unbound secondary antibody was then removed. The HRP conjugate solution was then added to every well including the zero wells. Following incubation excess conjugate was removed by careful washing. A chromogen substrate was added to the wells resulting in the progressive development of a blue coloured complex with the conjugate. The colour development was then stopped by the addition of acid turning the resultant final product yellow. The intensity of the produced coloured complex is directly proportional to the concentration of IL- 4 and IL-13 present in the samples and standards. The absorbance of the colour complex was then measured and the generated OD values for each standard are plotted against expected concentration forming a standard curve. This standard curve can then be used to accurately determine the concentration of IL-4 and IL-13 in as many samples tested. The primary wavelengths for IL- 4 and IL-13 measurement were $450 \mathrm{~nm}$ and $630 \mathrm{~nm}$, respectively.

\section{Sensitivity}

The sensitivity or minimum detectable dose of IL-4/ IL-13 using diaclone IL-4/IL-13 ELISA kit was found to be $0.3 \mathrm{pg} / \mathrm{ml}$ and $1.5 \mathrm{pg} / \mathrm{ml}$ respectively. This was determined by adding 3 standard deviations to the mean OD obtained when the zero standard was assayed 3-5 times. However, we had considered $0.7 \mathrm{pg} / \mathrm{ml}$ as the minimum value below which the interleukin levels were treated as undetectable in order to be in line with most of the currently used moderately sensitive ELISA kits.

\section{Genetic analysis}

Besides environmental and lifestyle factors, genetics factors also play an important role in the development of allergic disorders. Genetic variants of these interleukin genes have previously been associated with different allergic phenotypes [22] and a detailed account of different gene variants of $I L-4$ and $I L-13$ have been done as discussed elsewhere [23]. For identification of the studied genotypes, PCR-RFLP analysis was performed [24], the details of which are provided in Table 1.

\section{Statistical analysis}

Different categorical variables were set for calculating number and percentages for different genotypes of studied genes. Test for Hardy-Weinberg Equilibrium (HWE) were conducted by comparing observed and expected genotype distributions by the $\chi^{2}$ goodness of fit. Statistical significance for departure of a genotype frequency from its expected frequency under the HWE model was set at $P \leq 0.05$. Conditional logistic regression models were used to calculate odds ratios (ORs) and corresponding $95 \%$ confidence intervals (95\%CIs) to assess the association of the genotypes with allergies. All statistical analysis was done using STATA software, version 14 (STATA Corp., College Station, TX, USA). 
Table 1 Frequency distribution of selected demographic and risk factors in atopy cases and controls of the study

\begin{tabular}{|c|c|c|c|}
\hline Characteristics & $\begin{array}{l}\text { Cases } \\
(n=528)\end{array}$ & $\begin{array}{l}\text { Controls } \\
(n=610)\end{array}$ & $P_{\text {value }}$ \\
\hline \multicolumn{4}{|l|}{ Age years } \\
\hline$<40$ & $414(78.4)$ & $459(75.0)$ & \\
\hline$\geq 40$ & $114(21.6)$ & $151(25.0)$ & $>0.05$ \\
\hline Mean age & $29.7 \pm 13.9$ & $29.45 \pm 14.2$ & \\
\hline \multicolumn{4}{|l|}{ Gender } \\
\hline Male & $210(39.8)$ & $255(41.8)$ & \\
\hline Female & $318(60.2)$ & $355(58.2)$ & $>0.05$ \\
\hline \multicolumn{4}{|l|}{ Dwelling } \\
\hline Urban & $240(45.5)$ & $281(46.1)$ & \\
\hline Rural & $288(54.5)$ & $329(44.9)$ & $>0.05$ \\
\hline \multicolumn{4}{|l|}{ Smoking status } \\
\hline Smokers & $63(12.0)$ & $38(6.2)$ & $>0.05$ \\
\hline Non-smokers & $165(31.2)$ & $345(56.5)$ & \\
\hline Passive smokers & $300(56.8)$ & $227(37.3)$ & \\
\hline \multicolumn{4}{|l|}{ IgE levels } \\
\hline Normal $(<180 u / l)$ & $03(0.6)$ & $487(79.8)$ & $<0.05$ \\
\hline Elevated $(\geq 180 \mathrm{u} / \mathrm{l})$ & $525(99.4)$ & $123(20.2)$ & \\
\hline \multicolumn{4}{|l|}{ Eosinophil count } \\
\hline Normal (1.0-6.0\%) & $297(56.3)$ & $519(85.1)$ & \\
\hline Elevated (>6.0\%) & $231(43.7)$ & $91(14.9)$ & $>0.05$ \\
\hline \multicolumn{4}{|l|}{ Vitamin D levels (ng/ml) } \\
\hline Deficient $(<20)$ & $345(65.3)$ & $503(82.4)$ & $>0.05$ \\
\hline Insufficient (20-30) & $111(21.0)$ & $49(8.0)$ & \\
\hline Sufficient (31-100) & $72(13.7)$ & $58(9.6)$ & \\
\hline Upper safety limit (> 100) & $00(0.0)$ & $00(0.0)$ & \\
\hline \multicolumn{4}{|l|}{ ESR } \\
\hline Normal (<15 mm/hr in males and <20 in females) & $414(78.4)$ & & \\
\hline Elevated ( $\geq 15 \mathrm{~mm} / \mathrm{hr}$ in males and $\geq 20$ in females) & $114(21.6)$ & & \\
\hline \multicolumn{4}{|l|}{$\mathrm{PFT}$} \\
\hline Normal & $324(61.4)$ & & \\
\hline Abnormal & $204(38.6)$ & & \\
\hline \multicolumn{4}{|l|}{ SPT } \\
\hline Positive to HDM & $72(13.6)$ & & \\
\hline Positive to pollens & $39(7.3)$ & & \\
\hline Positive to HDM/pollens & $114(21.6)$ & & \\
\hline Positive to HDM/pollens/fungi /AE & $66(12.5)$ & & \\
\hline Positive to HDM/pollens/few foods/AE & $225(42.6)$ & & \\
\hline Negative & $12(2.2)$ & & \\
\hline \multicolumn{4}{|l|}{ Socio economic status } \\
\hline Good & $150(28.4)$ & & \\
\hline Average & $336(63.6)$ & & \\
\hline Poor & $42(8.0)$ & & \\
\hline \multicolumn{4}{|l|}{ Seasonal/year round } \\
\hline Year round & $387(73.3)$ & & \\
\hline Seasonal & $141(26.7)$ & & \\
\hline
\end{tabular}


Table 1 (continued)

\begin{tabular}{|c|c|c|c|}
\hline Characteristics & $\begin{array}{l}\text { Cases } \\
(n=528)\end{array}$ & $\begin{array}{l}\text { Controls } \\
(n=610)\end{array}$ & $P_{\text {value }}$ \\
\hline \multicolumn{4}{|l|}{ Peak time } \\
\hline Morning & $255(48.2)$ & & \\
\hline Evening & $249(47.1)$ & & \\
\hline Both & $24(4.5)$ & & \\
\hline \multicolumn{4}{|l|}{ Family history } \\
\hline Yes & $393(74.5)$ & & \\
\hline No & $135(25.5)$ & & \\
\hline \multicolumn{4}{|l|}{ Triggers } \\
\hline Dust & $174(32.9)$ & & \\
\hline Dust/irritant & $210(39.7)$ & & \\
\hline Temperature & $12(2.3)$ & & \\
\hline Irritants & $132(25.0)$ & & \\
\hline \multicolumn{4}{|l|}{ Co-morbidity } \\
\hline Diabetes & $24(4.5)$ & & \\
\hline Hypertension & $27(5.1)$ & & \\
\hline Diabetes/hypertension/obesity & $16(2.7)$ & & \\
\hline Hypothyroidism & $51(9.6)$ & & \\
\hline PCOD & $21(3.9)$ & & \\
\hline $\mathrm{Nil}$ & $389(73.6)$ & & \\
\hline \multicolumn{4}{|l|}{ Collateral diseases } \\
\hline Drug allergy & $60(11.5)$ & & \\
\hline Migraine & $120(22.7)$ & & \\
\hline Food allergy & $90(17.0)$ & & \\
\hline Migraine/food allergy & $09(1.7)$ & & \\
\hline Migraine/drug allergy & $06(1.1)$ & & \\
\hline $\mathrm{Nil}$ & $243(46.0)$ & & \\
\hline \multicolumn{4}{|l|}{ Diagnosis } \\
\hline AR/BA & $210(39.7)$ & & \\
\hline$A R / A D$ & $57(10.8)$ & & \\
\hline $\mathrm{AR} / \mathrm{CU}$ & $36(6.8)$ & & \\
\hline $\mathrm{AR} / \mathrm{BA} / \mathrm{AD}$ & $120(22.7)$ & & \\
\hline $\mathrm{AR} / \mathrm{BA} / \mathrm{CU}$ & $75(14.2)$ & & \\
\hline AR/BA/conjunctivitis & $12(2.3)$ & & \\
\hline $\mathrm{BA} / \mathrm{CU}$ & $18(3.4)$ & & \\
\hline
\end{tabular}

IgE Immunoglobulin E, GAD General anxiety disorder, MDD Major depressive disorder, ESR Eosinophil sedimentation rate, PFT Pulmonary function test, HDM House dust mite, $A E$ Animal epithelia, $A R$ Atopic rhinitis, $B A$ Bronchial asthma, $A D$ topic dermatitis, CU Chronic urticarial

Two sided $P$ values $<0.05$ were considered as statistically significant.

\section{Results}

\section{Characteristics of study subjects}

In this study $60.2 \%(n=318)$ of the cases were females and $39.8 \%(n=210)$ were males with a male:female ratio of $0.7: 1$. On the basis of age, the patients were grouped into two categories, less than $40(<40)$ and greater or equal to $40(\geq 40)$ years of age. The number of cases in the age group of $<40(n=414 ; 78.4 \%)$ exceeded as compared to $\geq 40$ years $(\mathrm{n}=114 ; 21.6 \%)$ with an overall mean age of $29.7 \pm 13.9$ years. Based on the smoking status, 63 (12\%) patients were smokers who were inclusively males, 165 (31.2\%) were non-smokers and 300 (56.8\%) were passive smokers. There were $525(99.4 \%)$ patient with elevated $(\geq 180 \mathrm{u} / \mathrm{l})$ IgE levels while as only $3(0.6 \%)$ patients had normal $(<180 \mathrm{u} / \mathrm{l}) \mathrm{IgE}$ levels. Other study variables of the study subjects with atopy are shown in Table 1.

Among controls, 58.2\% $(n=355)$ of the subjects were females and $41.8 \%(n=255)$ were females. The number of control subjects in the age group of $<40(n=459 ; 75.0 \%)$ 
exceeded than $\geq 40$ years $(\mathrm{n}=151 ; 25.0 \%)$. The mean age of the control subjects was $29.45 \pm 14.2$ years. Based on the smoking status, $38(6.2 \%)$ controls were smokers who were inclusively males, 345 (56.5\%) were non-smokers and 227 (37.3\%) were passive smokers. There were 123 (20.2\%) controls with elevated IgE levels while as 487 (79.8\%) had normal IgE levels. Other clinicopathological and clinico-epidemiological characteristics of controls are shown in Table 1.

There were no significant differences among cases and controls in terms of mean age, gender distribution and smoking, although, more non-smokers were present in controls than in cases (56.5\% vs $31.2 \%)$. Similarly, substantially higher number of case $(99.4 \%)$ showed increased serum IgE levels than controls (20.2\%).

\section{Serum cytokine levels (IL-4 \& IL-13) in cases and controls} In the present study we analyzed the serum IL-4 and IL-13 levels in cases and controls in order to evaluate their association with the risk of Atopy in Kashmiri population.

\section{Serum IL-4 levels and their association with demographic and clinicopathological characteristics of cases and controls}

The frequency of detectable IL-4 levels was found to be higher for cases (408 out of 528 i.e. $77.3 \%$ ) than controls (117 out of 610 i.e. 19.1\%), a difference which is statistically significant $(P<0.01)$. The median IL-4 levels in cases and controls was found to be $2.57(0.0-23.35)$ and $0.08(0.0-4.37)$ respectively (Table 2$)$.

On further stratification, association between IL-4 levels and clinico-pathological variables was analyzed between cases and controls. It was observed that there was a statistically significant difference in the frequency of detectable and undetectable IL-4 levels between cases and controls with respect to all the subgroups of IgE levels, age, gender, dwelling, smoking status, eosinophil count and vitamin D levels $(P<0.01)$ (Table 3$)$.

Frequency of detectable IL-4 levels was more common in cases with year round allergy as compared to patients with seasonal allergy $(\mathrm{OR}=0.5, P=0.01)$, in cases with other co-morbidities $(P=0.02)$ and patients with all the differential diagnosis of Atopy $(P=0.03)$ (Table 3$)$.

When the different studied polymorphisms of $I L-4 R A$, $I L-4, I L-13$ and STAT6 genes were compared with IL-4 levels of Atopy patients the statistical significance was noted with $I L-4 R A$ A148G $(\mathrm{OR}=2.0 ; \mathrm{P}=0.01), I L$ $13 \mathrm{~A} 1512 \mathrm{C}(\mathrm{OR}=0.5 ; \mathrm{P}=0.05)$ and STAT6 G2964A $(\mathrm{OR}=0.6 ; P=0.03)$ respectively (Table 4$)$.

\section{Serum IL-13 levels and their association with demographic and clinicopathological characteristics of cases and controls}

Detectable IL-13 levels in Atopy patients and matched controls were analysed in order to evaluate its association with the risk of Atopy in Kashmiri population. All cases had detectable IL-13 levels (528 of $528 ; 100.0 \%$ ) as compared to controls (395 of 610;64.7\%), a difference which is statistically significant $(\mathrm{P}<0.01)$. The median IL-13 levels in cases and controls were found to be 13.79 (5.98-42.47) and $2.32(0.0-6.51)$ respectively (Table 2). There was a significant difference between detectable and undetectable IL-13 levels of cases and controls $(\mathrm{P}<0.0001)$.

On comparing IL-13 with various clinicopathological variables, a statistically significant difference in the frequency of detectable and undetectable IL-13 levels were observed in both the groups with respect to all the subgroups of IgE, age, gender, dwelling, smoking status, levels, eosinophil count and vitamin D levels so consequently there was no overall statistical significance with respect to these clinicopathological characteristics $(P<0.0001)$. However, association between IL-13 levels and demographic/clinicopathological characteristics did not presented any significant association among cases $(\mathrm{P}>0.05)$ (Table 5).

When the different studied polymorphisms of $I L-4 R \alpha$, IL-4, IL-13 and STAT6 genes were compared with IL-13 levels of Atopy patients the statistical significance was not noted with any of the polymorphisms (Table 6).

Correlation analysis of various parameters between cases and controls is presented in Figs. 1, 2, 3 and 4. Most of the studied parameters showed a positive but significant correlation between cases and controls.

Table 2 The number of subjects with detectable serum $I L-4$ and $I L-13$ levels along with its median and range in patient and control group

\begin{tabular}{|c|c|c|c|c|c|}
\hline \multirow[t]{2}{*}{ Cytokines (pg/mL) } & \multicolumn{2}{|l|}{ Cases } & \multicolumn{2}{|l|}{ Controls } & \multirow[t]{2}{*}{$P$ value } \\
\hline & N (\%) & Median (min-max) & n (\%) & Median (min-max) & \\
\hline IL-4 & 408/528 (77.3) & $2.57(0.0-23.35)$ & $117 / 610(19.1)$ & $0.08(0.0-4.37)$ & $<0.01$ \\
\hline IL-13 & $528 / 528(100)$ & $13.79(5.98-42.47)$ & $395 / 610(64.7)$ & $2.32(0.0-6.51)$ & $<0.01$ \\
\hline
\end{tabular}


Table 3 Correlation of various clinico-pathological characteristics of cases and controls with serum IL-4 levels

\begin{tabular}{|c|c|c|c|c|c|c|c|c|}
\hline \multirow[t]{3}{*}{ Variables } & \multicolumn{3}{|l|}{ Cases } & \multicolumn{3}{|l|}{ Controls } & \multirow[t]{2}{*}{ OR $(95 \% \mathrm{Cl})$} & \multirow[t]{2}{*}{ P Value } \\
\hline & Number (n) & Un (\%) & Dn (\%) & Number (n) & Un (\%) & Dn (\%) & & \\
\hline & $\mathrm{n}=528$ & $120(22.7)$ & $408(77.3)$ & $n=610$ & $493(80.9)$ & $117(19.1)$ & $14.3(10.7-19.0)$ & $<0.0001$ \\
\hline \multicolumn{9}{|l|}{ Age } \\
\hline$<40$ & 414 (78.4) & 102 & 312 & $459(75.0)$ & 373 & 86 & $13.2(9.5-18.3)$ & $<0.0001$ \\
\hline$\geq 40$ & $114(21.6)$ & 18 & 96 & $151(25.0)$ & 120 & 31 & $20.6(10.8-39.1)$ & $<0.0001$ \\
\hline \multicolumn{9}{|l|}{ Gender } \\
\hline Male & $210(39.8)$ & 36 & 174 & $255(41.8)$ & 205 & 50 & $19.8(13.3-31.8)$ & $<0.0001$ \\
\hline Female & $318(60.2)$ & 84 & 234 & $355(58.2)$ & 288 & 67 & $11.9(8.3-17.2)$ & $<0.0001$ \\
\hline \multicolumn{9}{|l|}{ Dwelling } \\
\hline Urban & $240(45.5)$ & 48 & 192 & $281(46.1)$ & 221 & 60 & $14.7(9.6-22.5)$ & $<0.0001$ \\
\hline Rural & $288(54.5)$ & 72 & 216 & $329(44.9)$ & 272 & 57 & $14.3(9.6-21.1)$ & $<0.0001$ \\
\hline \multicolumn{9}{|l|}{ Smoking status } \\
\hline Smokers & $63(12.0)$ & 12 & 151 & $38(6.2)$ & 32 & 06 & $67.1(23.4-92.0)$ & $<0.0001$ \\
\hline Non-smokers & $165(31.2)$ & 42 & 123 & $345(56.5)$ & 187 & 40 & $1.36(8.3-22.3)$ & $<0.0001$ \\
\hline Passive smokers & $300(56.8)$ & 66 & 234 & $227(37.3)$ & 274 & 71 & $13.6(9.3-19.9)$ & $<0.0001$ \\
\hline \multicolumn{9}{|l|}{ IgE levels } \\
\hline Normal & $03(0.6)$ & 00 & 03 & $487(79.8)$ & 405 & 82 & $19.5(2.1-77.2)$ & $<0.0001$ \\
\hline Elevated & $525(99.4)$ & 120 & 405 & $123(20.2)$ & 88 & 35 & $8.4(5.4-13.1)$ & $<0.0001$ \\
\hline \multicolumn{9}{|l|}{ Eosinophil count } \\
\hline Normal & $297(56.3)$ & 75 & 222 & $519(85.1)$ & 419 & 100 & $12.4(8.8-17.4)$ & $<0.0001$ \\
\hline Elevated & $231(43.7)$ & 45 & 186 & $91(14.9)$ & 74 & 17 & $17.9(9.6-33.4)$ & $<0.0001$ \\
\hline \multicolumn{9}{|l|}{ Vitamin D levels (ng/ml) } \\
\hline Deficient $(<20)$ & $345(65.3)$ & 93 & 252 & $503(82.4)$ & 408 & 95 & $11.6(8.3-16.1)$ & $<0.0001$ \\
\hline Insufficient (20-30) & $111(21.0)$ & 15 & 96 & $49(8.0)$ & 40 & 09 & $28.4(11.5-70.3)$ & $<0.0001$ \\
\hline Sufficient (31-100) & $72(13.7)$ & 12 & 60 & $58(9.6)$ & 45 & 13 & $17.3(7.2-41.5)$ & $<0.0001$ \\
\hline ESR & & & & & & & $1.0(0.6-1.7)$ & 0.7 \\
\hline Normal & $414(78.4)$ & 93 & 321 & & & & & \\
\hline Elevated & $114(21.6)$ & 27 & 87 & & & & & \\
\hline PFT & & & & & & & $0.7(0.4-1.09)$ & 0.1 \\
\hline Normal & $324(61.4)$ & 81 & 243 & & & & & \\
\hline Abnormal & $204(38.6)$ & 39 & 165 & & & & & \\
\hline SPT & & & & & & & & 0.7 \\
\hline $\mathrm{HDM}$ & $72(13.6)$ & 15 & 57 & & & & & \\
\hline Pollens & $39(7.3)$ & 09 & 30 & & & & & \\
\hline HDM/pollens & $114(21.6)$ & 21 & 93 & & & & & \\
\hline HDM/pollens/fungi/AE & $66(12.5)$ & 24 & 42 & & & & & \\
\hline $\mathrm{HDM} /$ pollens/few foods/AE & $225(42.6)$ & 48 & 77 & & & & & \\
\hline Negative & $12(2.2)$ & 03 & 09 & & & & & \\
\hline Socio economic status & & & & & & & $1.6(0.98-2.5)$ & 0.06 \\
\hline Good & $150(28.4)$ & 27 & 123 & & & & & \\
\hline Average & $336(63.6)$ & 87 & 249 & & & & & \\
\hline Poor & $42(8.0)$ & 06 & 36 & & & & & \\
\hline \multicolumn{9}{|l|}{ Seasonal/year round } \\
\hline Year round & $387(73.3)$ & 99 & 288 & & & & & \\
\hline Seasonal & $141(26.7)$ & 21 & 120 & & & & $0.5(0.3-0.8)$ & 0.009 \\
\hline Peak time & & & & & & & $1.3(0.9-2.0)$ & 0.1 \\
\hline Morning & $255(48.2)$ & 51 & 204 & & & & $1.3(0.5-3.5)$ & 0.3 \\
\hline Evening & $249(47.1)$ & 63 & 186 & & & & & \\
\hline Both & $24(4.5)$ & 06 & 18 & & & & & \\
\hline
\end{tabular}


Table 3 (continued)

\begin{tabular}{|c|c|c|c|c|c|c|c|c|}
\hline \multirow[t]{3}{*}{ Variables } & \multicolumn{3}{|l|}{ Cases } & \multicolumn{3}{|l|}{ Controls } & \multirow[t]{2}{*}{ OR $(95 \% \mathrm{Cl})$} & \multirow[t]{2}{*}{ P Value } \\
\hline & Number (n) & Un (\%) & Dn (\%) & Number (n) & Un (\%) & Dn (\%) & & \\
\hline & $\mathrm{n}=\mathbf{5 2 8}$ & $120(22.7)$ & $408(77.3)$ & $n=610$ & $493(80.9)$ & $117(19.1)$ & $14.3(10.7-19.0)$ & $<0.0001$ \\
\hline Family history & & & & & & & $1.1(0.7-1.8)$ & 0.6 \\
\hline Yes & $393(74.5)$ & 87 & 306 & & & & & \\
\hline No & $135(25.5)$ & 33 & 102 & & & & & \\
\hline Triggers & & & & & & & & 0.2 \\
\hline Dust & $174(32.9)$ & 42 & 132 & & & & & \\
\hline Dust/irritant & $210(39.7)$ & 51 & 159 & & & & & \\
\hline Temperature & $12(2.3)$ & 03 & 9 & & & & & \\
\hline Irritants & $132(25.0)$ & 24 & 108 & & & & & \\
\hline \multicolumn{9}{|l|}{ Co-morbidity } \\
\hline Diabetes & $24(4.5)$ & 03 & 21 & & & & & \\
\hline Hypertension & $27(5.1)$ & 03 & 24 & & & & & \\
\hline Diabetes/hypertension/obesity & $16(2.7)$ & 00 & 16 & & & & & \\
\hline Hypothyroidism & $51(9.6)$ & 15 & 36 & & & & & \\
\hline PCOD & $21(3.9)$ & 03 & 18 & & & & & \\
\hline $\mathrm{Nil}$ & $389(73.6)$ & 96 & 293 & & & & & 0.02 \\
\hline Collateral diseases & & & & & & & & 0.3 \\
\hline Drug allergy & $60(11.5)$ & 12 & 48 & & & & & \\
\hline Migraine & $120(22.7)$ & 30 & 90 & & & & & \\
\hline Food allergy & $90(17.0)$ & 15 & 75 & & & & & \\
\hline Migraine/food allergy & $09(1.7)$ & 06 & 03 & & & & & \\
\hline Migraine/drug allergy & $06(1.1)$ & 00 & 06 & & & & & \\
\hline $\mathrm{Nil}$ & $243(46.0)$ & 57 & 186 & & & & & \\
\hline Diagnosis & & & & & & & & 0.03 \\
\hline AR/BA & $210(39.7)$ & 45 & 165 & & & & & \\
\hline$A R / A D$ & $57(10.8)$ & 06 & 51 & & & & & \\
\hline $\mathrm{AR} / \mathrm{CU}$ & $36(6.8)$ & 09 & 27 & & & & & \\
\hline $\mathrm{AR} / \mathrm{BA} / \mathrm{AD}$ & $120(22.7)$ & 27 & 93 & & & & & \\
\hline $\mathrm{AR} / \mathrm{BA} / \mathrm{CU}$ & $75(14.2)$ & 21 & 54 & & & & & \\
\hline AR/BA/conjunctivitis & $12(2.3)$ & 06 & 06 & & & & & \\
\hline $\mathrm{BA} / \mathrm{CU}$ & $18(3.4)$ & 06 & 12 & & & & & \\
\hline
\end{tabular}

IL Interleukin, $U$ undetectable, $D$ detectable, IgE immunoglobulin $\mathrm{E}, G A D$ general anxiety disorder, $M D D$ major depressive disorder, ESR eosinophil sedimentation rate, LSCS lower segment caesarian section, TSH thyroid stimulating hormone, PFT pulmonary function test, HDM house dust mite, $A E$ animal epithelia, $A R$ atopic rhinitis, BA bronchial asthma, $A D$ topic dermatitis, $C U$ chronic urticaria

$0.7 \mathrm{pg} / \mathrm{ml}$ is the minimum value below which the interleukin levels (IL-4) were treated as undetectable

\section{Discussion}

IgE plays an important role in the development of allergic disorders. Current evidence shows that high-affinity IgE in blood stream of allergic individuals derives mainly from the mucous membrane. The production of IgE requires the activation of the adaptive immune system. $\mathrm{B}$ cells in the secondary lymphoid organs are stimulated to produce mature antibodies [25]. Moreover, the stimulus upon exposure of allergens in the mucosa might produce a sequential switching to IgE from IgG or IgA [26, 27]. A study from early 1990s demonstrated that house dust mite-specific IgE increased faster in the nasal secretions than in serum after allergen exposure [28]. Similarly allergic rhinites patients on exposure to pollen showed significant changes in IgE repertoires in nasal mucosa $[29,30]$.

Different cytokines are modulating factors of the immune response and inflammatory reactions and are involved in the pathogenesis of allergies. In this study, we observed a substantial increase in serum IgE levels among atopic subjects as compared to non-atopic controls $(P<0.05)$. In subjects with increased levels of 
Table 4 Correlation of various genetic variants with serum IL-4 levels in Atopy patients

\begin{tabular}{|c|c|c|c|c|c|}
\hline \multirow[t]{4}{*}{ Overall genotype } & \multicolumn{3}{|l|}{ Cases } & \multirow[t]{4}{*}{ OR $(95 \% \mathrm{Cl})$} & \multirow[t]{4}{*}{$P$ value } \\
\hline & Number & U & D & & \\
\hline & (n) & n (\%) & n (\%) & & \\
\hline & $n=528$ & $120(22.7)$ & $408(77.3)$ & & \\
\hline IL-4 RA (A148G) & & & & $2.0(1.1-3.7)$ & 0.01 \\
\hline $\mathrm{AA}$ & $108(20.4)$ & 15 & 93 & & \\
\hline$A G+G G$ & $420(79.6)$ & 105 & 315 & & \\
\hline IL-4RA (A1902G) & & & & $1.5(0.8-2.5)$ & 0.17 \\
\hline AA & $102(19.3)$ & 18 & 84 & & \\
\hline$A G+G G$ & $426(70.7)$ & 102 & 324 & & \\
\hline IL-4 70 bp VNTR & & & & $0.8(0.5-1.3)$ & 0.4 \\
\hline 2 repeats & $93(17.6)$ & 24 & 69 & & \\
\hline 2/3 repeats & $435(72.4)$ & 96 & 339 & & \\
\hline IL-13 (C1055T) & & & & $0.8(0.5-1.2)$ & 0.4 \\
\hline CC & $207(39.2)$ & 51 & 156 & & \\
\hline $\mathrm{CT}+\mathrm{TT}$ & $321(60.8)$ & 69 & 252 & & \\
\hline IL-13 (A1512C) & & & & $0.5(0.3-0.8)$ & 0.005 \\
\hline AA & $99(18.7)$ & & & & \\
\hline$A C+C C$ & $429(71.3)$ & 33 & 66 & & \\
\hline STAT-6 (G2964A) & & & & $0.6(0.4-0.95)$ & 0.03 \\
\hline GG & $156(29.5)$ & 87 & 342 & & \\
\hline $\mathrm{GA}+\mathrm{AA}$ & $372(70.5)$ & 75 & 297 & & \\
\hline
\end{tabular}

IL Interleukin, $U$ undetectable, $D$ detectable

$0.7 \mathrm{pg} / \mathrm{ml}$ is the minimum value below which the interleukin levels (IL-4) were treated as undetectable

$1.5 \mathrm{pg} / \mathrm{ml}$ is the minimum value below which the interleukin levels (IL-13) were treated as undetectable

serum IgE levels, we observed higher percentage of variant genotypes of $I L-4$ and $I L-13$ genes. Additionally, there was an increased serum IL-4 and IL-13 levels among atopic patients as compared to controls.

Our results are completely in agreement with earlier epidemiological studies which reported higher IgE levels associated with bronchial responsiveness, a major component of the asthma phenotype, rhinitis and dermatitis [31-33]. In recent years, a high serum levels of IgE is used to predict the development of asthma, independent of other allergic factors. Therefore, an understanding of the genetic mechanisms regulating total serum IgE levels will be effective to scrutinize the hereditary components of different atopic disorders, complex genetic disorders influenced by the interactions among multiple genes and environmental exposures [34]. In another study, a two-locus segregation analysis revealed evidence of two major gene locus on chromosome 5 (5q31-533) and a residual genetic effect regulating total serum IgE levels in asthma patients [35]. Several studies have found evidence for a recessive gene regulating IgE levels, with different estimates of gene frequencies and mean IgE levels [36].
$I L-13$ and $I L-4$ genes have been reported to play an important role in allergy $[37,38]$. They recruit eosinophils and mast cells, induce B-cells for IgE synthesis [39]. In addition, $I L-4$ is also responsible for regulating differentiation of naive $\mathrm{T}$ cells into Th2 subtype. In response to allergen IL-4 strongly influence bronchial hyperactivity resulting in airway inflammation, mucus hypersecretion and airway remodelling [20]. Previous studies have shown that SNPs in the $I L-4$ promoter may influence the response of mast cells to IgEmediated signaling [16]. Polymorphism rs2243250 was associated with IgE levels, asthma, rhinitis and dermatitis [40, 41]. The studied polymorphism of $I L-4$ has also been associated with different topic disorders like atopic asthma and increased total IgE level [42]. In $I L-13$ gene, a functional SNP contributing to amino acid substitution R110Q (rs20541) was described to change the binding strength of $I L-13$ to its receptor, causing higher activity of Gln110 variant [17]. Numerous studies showed that this polymorphism correlated significantly with higher total IgE levels among allergic patients [38, 43]. Furthermore, study by Choi et al. describes significant association with an increase in total serum IgE levels in 
Table 5 Correlation of various clinic-pathological characteristics of cases and controls with $/ L-13$ serum levels

\begin{tabular}{|c|c|c|c|c|c|c|c|c|}
\hline \multirow[t]{4}{*}{ Variables } & \multicolumn{3}{|l|}{ Cases } & \multicolumn{3}{|l|}{ Controls } & \multirow[t]{3}{*}{ OR $(95 \% \mathrm{Cl})$} & \multirow[t]{3}{*}{$P$ value } \\
\hline & Number (n) & Un (\%) & D & Number & Un (\%) & Dn (\%) & & \\
\hline & & & n (\%) & (n) & & & & \\
\hline & $n=528$ & $00(00.00)$ & $528(100.0)$ & $n=610$ & $215(35.3)$ & 395 (64.7) & - & $<0.0001$ \\
\hline Age & & & & & & & - & \\
\hline$<40$ & $414(78.4)$ & 00 & 414 & $459(75.0)$ & 158 & 301 & & $<0.0001$ \\
\hline$\geq 40$ & $114(21.6)$ & 00 & 114 & $151(25.0)$ & 57 & 94 & & $<0.0001$ \\
\hline Gender & & & & & & & - & \\
\hline Male & $210(39.8)$ & 00 & 310 & $255(41.8)$ & 83 & 172 & & $<0.0001$ \\
\hline Female & $318(60.2)$ & 00 & 318 & $355(58.2)$ & 132 & 223 & & $<0.0001$ \\
\hline Dwelling & & & & & & & - & \\
\hline Urban & $240(45.5)$ & 00 & 240 & $281(46.1)$ & 108 & 173 & & $<0.0001$ \\
\hline Rural & $288(54.5)$ & 00 & 288 & $329(44.9)$ & 107 & 222 & & $<0.0001$ \\
\hline Smoking status & & & & & & & - & \\
\hline Smokers & $63(12.0)$ & 00 & 63 & $38(6.2)$ & 12 & 26 & & $<0.0001$ \\
\hline Non-smokers & $165(31.2)$ & 00 & 165 & $345(56.5)$ & 80 & 147 & & $<0.0001$ \\
\hline Passive smokers & $300(56.8)$ & 00 & 300 & $227(37.3)$ & 123 & 222 & & $<0.0001$ \\
\hline IgE Levels: & & & & & & & - & \\
\hline Normal & $03(0.6)$ & 00 & 3 & $487(79.8)$ & 175 & 312 & & $<0.0001$ \\
\hline Elevated & $525(99.4)$ & 00 & 525 & $123(20.2)$ & 40 & 83 & & $<0.0001$ \\
\hline Eosinophil count & & & & & & & - & \\
\hline Normal & $297(56.3)$ & 00 & 297 & $519(85.1)$ & 183 & 336 & & $<0.0001$ \\
\hline Elevated & $231(43.7)$ & 00 & 231 & $91(14.9)$ & 32 & 59 & & $<0.0001$ \\
\hline Vitamin D levels (ng/ml) & & & & & & & - & \\
\hline Deficient $(<20)$ & $345(65.3)$ & 00 & 345 & $503(82.4)$ & 173 & 330 & & $<0.0001$ \\
\hline Insufficient (20-30) & $111(21.0)$ & 00 & 111 & $49(8.0)$ & 18 & 31 & & $<0.0001$ \\
\hline Sufficient (31-100) & $72(13.7)$ & 00 & 72 & $58(9.6)$ & 24 & 34 & & $<0.0001$ \\
\hline ESR & & & & & & & - & 0.3 \\
\hline Normal & $414(78.4)$ & 00 & 414 & & & & & \\
\hline Elevated & $114(21.6)$ & 00 & 114 & & & & & \\
\hline PFT & & & & & & & - & 0.6 \\
\hline Normal & $324(61.4)$ & 00 & 324 & & & & & \\
\hline Abnormal & $204(38.6)$ & 00 & 204 & & & & & \\
\hline SPT & & & & & & & - & \\
\hline HDM & $72(13.6)$ & 00 & 72 & & & & & \\
\hline Pollens & $39(7.3)$ & 00 & 39 & & & & & \\
\hline HDM/pollens & $114(21.6)$ & 00 & 114 & & & & & \\
\hline HDM/pollens/fungi /AE & $66(12.5)$ & 00 & 66 & & & & & \\
\hline $\mathrm{HDM} /$ pollens/few foods/AE & $225(42.6)$ & 00 & 225 & & & & & \\
\hline Negative & $12(2.2)$ & 00 & 12 & & & & & \\
\hline Socio economic status & & & & & & & - & 0.5 \\
\hline Good & $150(28.4)$ & 00 & 150 & & & & & 0.4 \\
\hline Average & $336(63.6)$ & 00 & 336 & & & & & \\
\hline Poor & $42(8.0)$ & 00 & 42 & & & & & \\
\hline Seasonal/year round & & & & & & & - & 0.4 \\
\hline Year round & $387(73.3)$ & 00 & 387 & & & & & \\
\hline Seasonal & $141(26.7)$ & 00 & 141 & & & & & \\
\hline
\end{tabular}


Table 5 (continued)

\begin{tabular}{|c|c|c|c|c|c|c|c|c|}
\hline \multirow[t]{4}{*}{ Variables } & \multicolumn{3}{|l|}{ Cases } & \multicolumn{3}{|l|}{ Controls } & \multirow[t]{3}{*}{ OR $(95 \% \mathrm{Cl})$} & \multirow[t]{3}{*}{ P value } \\
\hline & Number (n) & Un (\%) & D & Number & Un (\%) & Dn (\%) & & \\
\hline & & & n (\%) & & & & & \\
\hline & $n=528$ & $00(00.00)$ & $528(100.0)$ & $n=610$ & $215(35.3)$ & $395(64.7)$ & - & $<0.0001$ \\
\hline Peak time & & & & & & & - & 0.7 \\
\hline Morning & $255(48.2)$ & 00 & 255 & & & & & 0.1 \\
\hline Evening & $249(47.1)$ & 00 & 249 & & & & & \\
\hline Both & $24(4.5)$ & 00 & 24 & & & & & \\
\hline Family history & & & & & & & - & 0.5 \\
\hline Yes & $393(74.5)$ & 00 & 393 & & & & & \\
\hline No & $135(25.5)$ & 00 & 135 & & & & & \\
\hline Triggers & & & & & & & - & - \\
\hline Dust & $174(32.9)$ & 00 & 174 & & & & & \\
\hline Dust/irritant & $210(39.7)$ & 00 & 210 & & & & & \\
\hline Temperature & $12(2.3)$ & 00 & 12 & & & & & \\
\hline Irritants & $132(25.0)$ & 00 & 132 & & & & & \\
\hline Co-morbidity & & & & & & & - & - \\
\hline Diabetes & $24(4.5)$ & 00 & 24 & & & & & \\
\hline Hypertension & $27(5.1)$ & 00 & 27 & & & & & \\
\hline Diabetes/hypertension/obesity & $16(2.7)$ & 00 & 16 & & & & & \\
\hline Hypothyroidism & $51(9.6)$ & 00 & 51 & & & & & \\
\hline PCOD & $21(3.9)$ & 00 & 21 & & & & & \\
\hline Nil & $389(73.6)$ & 00 & 389 & & & & & \\
\hline Collateral diseases & & & & & & & - & - \\
\hline Drug allergy & $60(11.5)$ & 00 & 60 & & & & & \\
\hline Migraine & $120(22.7)$ & 00 & 120 & & & & & \\
\hline Food allergy & $90(17.0)$ & 00 & 90 & & & & & \\
\hline Migraine/food allergy & $09(1.7)$ & 00 & 9 & & & & & \\
\hline Migraine/drug allergy & $06(1.1)$ & 00 & 6 & & & & & \\
\hline $\mathrm{Nil}$ & $243(46.0)$ & 0 & 243 & & & & & \\
\hline Diagnosis & & & & & & & - & - \\
\hline AR/BA & $210(39.7)$ & 00 & 210 & & & & & \\
\hline$A R / A D$ & $57(10.8)$ & 00 & 57 & & & & & \\
\hline $\mathrm{AR} / \mathrm{CU}$ & $36(6.8)$ & 00 & 36 & & & & & \\
\hline $\mathrm{AR} / \mathrm{BA} / \mathrm{AD}$ & $120(22.7)$ & 00 & 120 & & & & & \\
\hline $\mathrm{AR} / \mathrm{BA} / \mathrm{CU}$ & $75(14.2)$ & 00 & 75 & & & & & \\
\hline AR/BA/conjunctivitis & $12(2.3)$ & 00 & 12 & & & & & \\
\hline $\mathrm{BA} / \mathrm{CU}$ & $18(3.4)$ & 00 & 18 & & & & & \\
\hline
\end{tabular}

IL Interleukin, U undetectable, $D$ detectable, IgE immunoglobulin E, GAD general anxiety disorder, MDD major depressive disorder, ESR eosinophil sedimentation rate, LSCSlower segment caesarian section, TSH thyroid stimulating hormone, PFT pulmonary function test, HDM house dust mite, AE animal epithelia, AR atopic rhinitis, $B A$ bronchial asthma, $A D$ atopic dermatitis, $C U$ chronic urticaria

$1.5 \mathrm{pg} / \mathrm{ml}$ is the minimum value below which the interleukin levels (IL-13) were treated as undetectable

children with atopic asthma in Korean population for rs20541 and rs1805010 polymorphisms [44], which is completely in agreement with our results. In allergic subjects, Th2 phenotype predominates, leading to increased production of serum IL-13 and class-switching in B lymphocytes to synthesize IgE antibodies [45, 46].
Arima et al. have found, using animal model, that $I L-13$ with $G \ln 110$ variant has higher activity and is present in blood for a longer time [17]. This was confirmed by Chen et al. $[47,48]$, who performed the experiments on mouse cell line with stable expression of human $I L-13 R$, that had the ability to bind human $I L-13$ gene. In agreement with 
Table 6 Correlation of various genetic variants with $/ L-13$ levels of cases and controls

\begin{tabular}{|c|c|c|c|c|c|}
\hline \multirow{2}{*}{$\begin{array}{l}\text { Overall genotype/ } \\
\text { IL-4 levels }\end{array}$} & \multicolumn{3}{|l|}{ Cases } & \multirow[t]{2}{*}{ OR $(95 \% \mathrm{Cl})$} & \multirow[t]{2}{*}{$P$ value } \\
\hline & Number (n) & Un (\%) & D n (\%) & & \\
\hline & $n=528$ & $00(00.0)$ & $528(100.0)$ & & \\
\hline IL-4 RA (A148G) & & & & $0.2(0.01-4.1)$ & 0.4 \\
\hline $\mathrm{AA}$ & $108(20.4)$ & 00 & 108 & & \\
\hline$A G+G G$ & $420(79.6)$ & 00 & 420 & & \\
\hline IL-4RA (A1902G) & & & & $0.2(0.01-3.8)$ & 0.3 \\
\hline AA & $102(19.3)$ & 00 & 102 & & \\
\hline $\mathrm{AG}+\mathrm{GG}$ & $426(70.7)$ & 00 & 426 & & \\
\hline IL-4 70 bp VNTR & & & & $0.2(0.01-3.4)$ & 0.3 \\
\hline 2 repeats & $93(17.6)$ & 00 & 93 & & \\
\hline $2 / 3$ repeats & $435(72.4)$ & 00 & 435 & & \\
\hline IL-13 (C1055T) & & & & $0.6(0.04-10.3)$ & 0.6 \\
\hline CC & 207 (39.2) & 00 & 207 & & \\
\hline $\mathrm{CT}+\mathrm{TT}$ & $321(60.8)$ & 00 & 321 & & \\
\hline IL-13 (A1512C) & & & & $0.2(0.01-3.7)$ & 0.3 \\
\hline $\mathrm{AA}$ & 99 (18.7) & 00 & 99 & & \\
\hline$A C+C C$ & $429(71.3)$ & 00 & 429 & & \\
\hline \multicolumn{6}{|l|}{ STAT-6 (G2964A) } \\
\hline GG & $156(29.5)$ & 00 & 156 & $0.4(0.02-6.7)$ & 0.5 \\
\hline$G A+A A$ & $372(70.5)$ & 00 & 372 & & \\
\hline
\end{tabular}

IL Interleukin, U undetectable, $D$ detectable

$0.7 \mathrm{pg} / \mathrm{ml}$ is the minimum value below which the interleukin levels (IL-4) were treated as undetectable

$1.5 \mathrm{pg} / \mathrm{ml}$ is the minimum value below which the interleukin levels (IL-13) were treated as undetectable

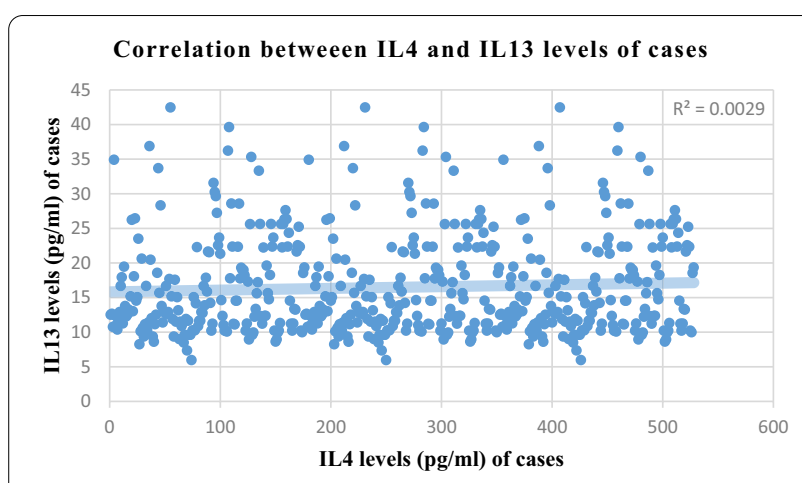

Fig. 1 Correlation analysis of various parameters between cases and controls Association is significant with positive but low correlation among all parameters correlated above

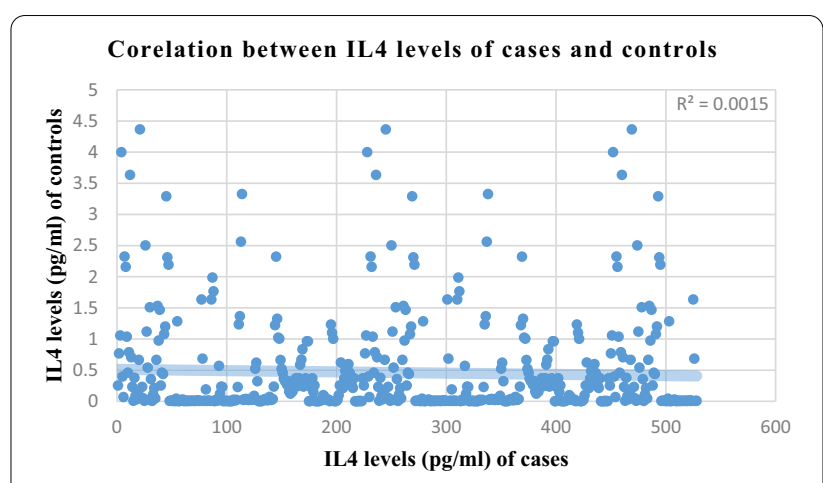

Fig. 2 Correlation analysis of various parameters between cases and controls Association is significant with positive but low correlation among all parameters correlated above the above findings, we observed a significant increase in IgE levels among subjects harboring the variant forms of studied genes.

\section{Conclusion}

The current findings suggest that IgE and interleukin genes play a key role in allergy disease development. Significantly raised serum levels of IgE, as well as both of the study's inflammatory markers were observed among cases as compared to controls. With respect to several subgroups including serum IgE levels, age, gender, residence, smoking status, eosinophil count, and vitamin $\mathrm{D}$ levels, there was a significant difference in the frequency of detectable and undetectable IL-4 and IL-13 levels between patients and controls. Only a few genotypes exhibited a significant difference between 


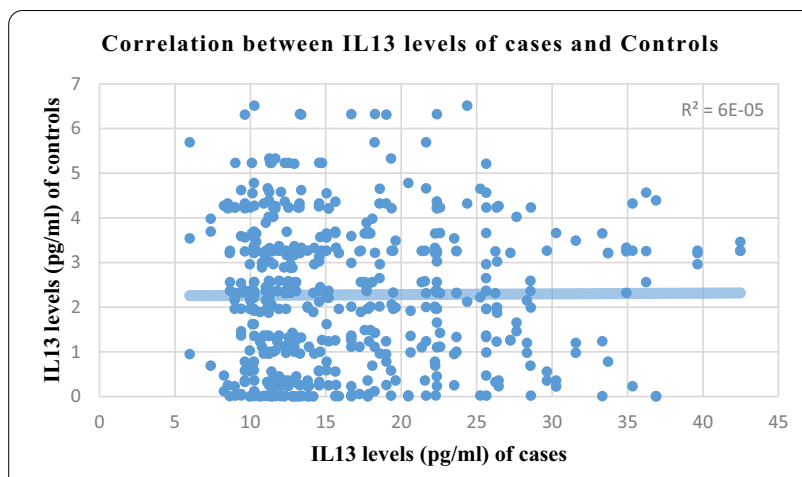

Fig. 3 Correlation analysis of various parameters between cases and controls Association is significant with positive but low correlation among all parameters correlated above

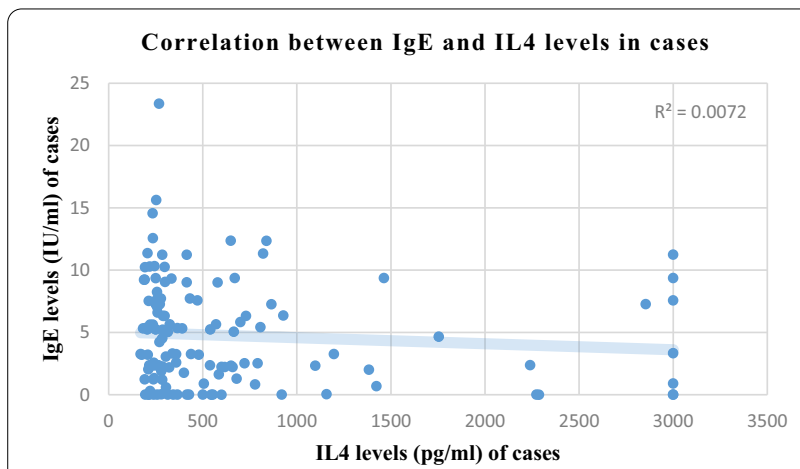

Fig. 4 Correlation analysis of various parameters between cases and controls Association is significant with positive but low correlation among all parameters correlated above

detectable and undetectable IL-4 serum levels, while IL-13 levels revealed no significant difference.

The strength of the study is that no study has reported the exposure of these genotypes with atopic disorders alone or in combination with these environmental exposures in Kashmiri population. Other major strength is comparatively larger sample size and confounding of the results with the probable allergy risk factors. However, selection or recall bias could be the weak point of this study, although the same hospital setting and only a single interviewer lessen this bias.

\section{Acknowledgements}

The authors gratefully acknowledge the volunteer participation of patients. The authors are also thankful to technical staff of the Department of Clinical Biochemistry and Department of Immunology, Molecular Medicine for their support.

\section{Authors' contributions}

TAQ - Concept, design of study, data collection and article draft; AS, GAB, MSK - Data collection, data analysis, interpretation and manuscript review RR -Provided Patient samples and SM — Concept and study design. All authors read and approved the final manuscript.

\section{Funding}

Not funding was received for the said study. The authors utilized their own expenses.

\section{Availability of data and materials \\ Not applicable.}

\section{Declarations}

Ethics approval and consent for participate

A written consent was taken from all the patients prior to their recruitment; they were also apprised about the ongoing study, which was approved by Institutional Ethical Clearance Committee of Sher-I-Kashmir Institute of Medical Sciences Srinagar, India vide order No. SIMS 1 131/IEC-

SKIMS/2016-133. A written pre-informed consent was obtained from all cases and controls.

\section{Consent to publication}

All authors have approved the manuscript for submission and possible publication.

\section{Competing interests}

The authors declare that there is no conflict of interests in the form of financial and personal relationships with other people or organizations that could lead to any kind of bias.

\section{Author details}

${ }^{1}$ Department of Clinical Biochemistry, Sher-I-Kashmir Institute of Medical Sciences, Srinagar 190011, India. ${ }^{2}$ Department of Biochemistry, SKIMS Medical College, Srinagar 190006, India. ${ }^{3}$ Department of Immunology and Molecular Medicine, SKIMS, Srinagar 190011, India.

Received: 19 June 2021 Accepted: 5 November 2021

\section{References}

1. Asher MI, Montefort S, Bjorksten B, et al. Worldwide time trends in the prevalence of symptoms of asthma, allergic rhinoconjunctivitis, and eczema in childhood: ISAAC Phases One and Three repeat multicountry cross-sectional surveys. Lancet. 2006;368(9537):733-43.

2. Deckers IA, McLean S, Linssen S, Mommers M, van Schayck CP, Sheikh A. Investigating international time trends in the incidence and prevalence of atopic eczema 1990-2010: a systematic review of epidemiological studies. PLoS ONE. 2012;7(7):e39803.

3. Paramesh H. Epidemiology of asthma in India. Indian J Pediatr. 2002;69(4):309-12.

4. Akdis CA. Allergy and hypersensitivity: mechanisms of allergic disease. Curr Opin Immunol. 2006;18(6):718-26.

5. Chatzi L, Alegakis A, Tzanakis N, Siafakas N, Kogevinas M, Lionis C. Association of allergic rhinitis with pesticide use among grape farmers in Crete, Greece. Occup Environ Med. 2007;64(6):417-21.

6. Marsh DG, Hsu SH, Roebber M, et al. HLA-Dw2: a genetic marker for human immune response to short ragweed pollen allergen Ra5. I. Response resulting primarily from natural antigenic exposure. J Exp Med. 1982:155(5):1439-51.

7. Barnes PJ. Immunology of asthma and chronic obstructive pulmonary disease. Nat Rev Immunol. 2008;8(3):183-92.

8. Granada M, Wilk JB, Tuzova M, et al. A genome-wide association study of plasma total IgE concentrations in the Framingham Heart Study. J Allergy Clin Immunol. 2012;129(3):840-5.

9. Hirota T, Takahashi A, Kubo M, et al. Genome-wide association study identifies eight new susceptibility loci for atopic dermatitis in the Japanese population. Nat Genet. 2012;44(11):1222-6.

10. Li X, Ampleford EJ, Howard TD, et al. Genome-wide association studies of asthma indicate opposite immunopathogenesis direction from autoimmune diseases. J Allergy Clin Immunol. 2012;130(4):861-8. 
11. Weidinger S, Gieger C, Rodriguez E, et al. Genome-wide scan on total serum IgE levels identifies FCER1A as novel susceptibility locus. PLoS Genetics. 2008;4(8):e1000166.

12. Basehore MJ, Howard TD, Lange LA, et al. A comprehensive evaluation of IL4 variants in ethnically diverse populations: association of total serum IgE levels and asthma in white subjects. J Allergy Clin Immunol. 2004;114(1):80-7.

13. Micheal S, Minhas K, Ishaque M, Ahmed F, Ahmed A. IL-4 gene polymorphisms and their association with atopic asthma and allergic rhinitis in Pakistani patients. J Investig Allergol Clin Immunol. 2013;23(2):107-11.

14. Mitsuyasu H, Izuhara K, Mao X-Q, et al. Ile50Val variant of IL4Ra upregulates IgE synthesis and associates with atopic asthma. Nat Genet 1998;19(2):119.

15. Liu S, Li T, Liu J. Interleukin-4 rs 2243250 polymorphism is associated with asthma among Caucasians and related to atopic asthma. Cytokine. 2012;59(2):364-9.

16. Amirzargar AA, Movahedi M, Rezaei N, et al. Polymorphisms in IL4 and iLARA confer susceptibility to asthma. J Investig Allergol Clin Immunol. 2009;19(6):433-8.

17. Arima K, Umeshita-Suyama R, Sakata Y, et al. Upregulation of IL-13 concentration in vivo by the IL13 variant associated with bronchial asthma. J Allergy Clin Immunol. 2002;109(6):980-7.

18. Barnes KC, Neely JD, Duffy DL, et al. Linkage of asthma and total serum IgE concentration to markers on chromosome 12q: evidence from AfroCaribbean and Caucasian populations. Genomics. 1996;37(1):41-50.

19. Kabesch M, Tzotcheva I, Carr D, et al. A complete screening of the IL4 gene: novel polymorphisms and their association with asthma and IgE in childhood. J Allergy Clin Immunol. 2003;112(5):893-8.

20. Heinzmann A, Mao XQ, Akaiwa M, et al. Genetic variants of IL-13 signalling and human asthma and atopy. Hum Mol Genet. 2000:9(4):549-59.

21. Alhajj M, Farhana AJS. Enzyme linked immunosorbent assay. 2021.

22. Delves PJ. Human leukocyte antigen (HLA) system. Merck Manual for Healthcare Professionals [On-line information]. 2016.

23. Qurashi TA, Bhat GA, Khan MS, et al. Interleukin 4 and Interleukin 4 receptor alpha gene variants and risk of atopy - a case control study based assessment. Clin Immunol. 2021;1:108783.

24. Jarcho J. Restriction fragment length polymorphism analysis. Curr Prot Human Genet. 1994;1(1):2-7.

25. Klein U, Dalla-Favera R. Germinal centres: role in B-cell physiology and malignancy. Nat Rev Immunol. 2008;8(1):22-33.

26. Coker HA, Durham SR, Gould HJ. Local somatic hypermutation and class switch recombination in the nasal mucosa of allergic rhinitis patients. J Immunol. 2003;171(10):5602-10.

27. Takhar P, Smurthwaite L, Coker HA, et al. Allergen drives class switching to IgE in the nasal mucosa in allergic rhinitis. J Immunol. 2005; 174(8):5024-32

28. Sensi LG, Piacentini GL, Nobile E, et al. Changes in nasal specific IgE to mites after periods of allergen exposure-avoidance: a comparison with serum levels. Clin Exp Allergy. 1994;24(4):377-82.

29. Borish L, Chipps B, Deniz Y, Gujrathi S, Zheng B, Dolan CM. Total serum IgE levels in a large cohort of patients with severe or difficult-to-treat asthma. Ann Allergy Asthma Immunol. 2005;95(3):247-53.

30. Wu YC, James LK, Vander Heiden JA, et al. Influence of seasonal exposure to grass pollen on local and peripheral blood lgE repertoires in patients with allergic rhinitis. J Allergy Clin Immunol. 2014;134(3):604-12.
31. Millares $L$, Bermudo $G$, Perez-Brocal $V$, et al. The respiratory microbiome in bronchial mucosa and secretions from severe lgE-mediated asthma patients. BMC Microbiol. 2017:17(1):20.

32. Rondon C, Eguiluz-Gracia I, Shamji MH, et al. IgE test in secretions of patients with respiratory allergy. Curr Allergy Asthma Rep. 2018;18(12):67.

33. Smoldovskaya O, Feyzkhanova G, Voloshin S, et al. Allergen-specific lgE and lgG4 patterns among patients with different allergic diseases. World Allergy Organ J. 2018;11(1):35

34. Wiesch DG, Meyers DA, Bleecker ER. Genetics of asthma. J Allergy Clin Immunol. 1999;104(5):895-901.

35. Xu J, Levitt RC, Panhuysen $\mathrm{Cl}$, et al. Evidence for two unlinked loci regulating total serum IgE levels. Am J Hum Genet. 1995;57(2):425-30.

36. Gerrard JW, Rao DC, Morton NE. A genetic study of immunoglobulin E. Am J Hum Genet. 1978;30(1):46-58.

37. Lee GR, Fields PE, Griffin TJ, Flavell RA. Regulation of the Th2 cytokine locus by a locus control region. Immunity. 2003;19(1):145-53.

38. Cui L, Jia J, Ma CF, et al. IL-13 polymorphisms contribute to the risk of asthma: a meta-analysis. Clin Biochem. 2012;45(4-5):285-8.

39. Cui T, Wu J, Pan S, Xie J. Polymorphisms in the IL-4 and IL-4R [alpha] genes and allergic asthma. Clin Chem Lab Med. 2003:41(7):888-92.

40. de Guia RM, Ramos JD. The -590C/TIL4 single-nucleotide polymorphism as a genetic factor of atopic allergy. Int J Mol Epidemiol Genet. 2010;1(1):67-73.

41. Beghe B, Barton S, Rorke S, et al. Polymorphisms in the interleukin-4 and interleukin-4 receptor a chain genes confer susceptibility to asthma and atopy in a Caucasian population. Clin Exp Allergy. 2003;33(8):1111-7.

42. Mitsuyasu $H$, Yanagihara $Y$, Mao XQ, et al. Cutting edge: dominant effect of Ile50Val variant of the human IL-4 receptor alpha-chain in IgE synthesis. J Immunol. 1999;162(3):1227-31.

43. DeMeo DL, Lange C, Silverman EK, et al. Univariate and multivariate family-based association analysis of the IL-13 ARG130GLN polymorphism in the Childhood Asthma Management Program. Genet Epidemiol. 2002;23(4):335-48.

44. Choi WA, Kang MJ, Kim YJ, et al. Gene-gene interactions between candidate gene polymorphisms are associated with total IgE levels in Korean children with asthma. J Asthma. 2012;49(3):243-52.

45. Namkung JH, Lee JE, Kim E, et al. Association of polymorphisms in genes encoding IL-4, IL-13 and their receptors with atopic dermatitis in a Korean population. Exp Dermatol. 2011;20(11):915-9.

46. Lu M-P, Chen R-X, Wang M-L, et al. Association study on IL4, IL13 and IL4RA polymorphisms in mite-sensitized persistent allergic rhinitis in a Chinese population. PLoS ONE. 2011:6(11):e27363.

47. Chen W, Ericksen MB, Levin LS, Khurana Hershey GK. Functional effect of the R110Q IL13 genetic variant alone and in combination with IL4RA genetic variants. J Allergy Clin Immunol. 2004;114(3):553-60.

48. Paternoster L, Standl M, Chen CM, et al. Meta-analysis of genome-wide association studies identifies three new risk loci for atopic dermatitis. Nat Genet. 2011;44(2):187-92

\section{Publisher's Note}

Springer Nature remains neutral with regard to jurisdictional claims in published maps and institutional affiliations.

Ready to submit your research? Choose BMC and benefit from

- fast, convenient online submission

- thorough peer review by experienced researchers in your field

- rapid publication on acceptance

- support for research data, including large and complex data types

- gold Open Access which fosters wider collaboration and increased citations

- maximum visibility for your research: over 100M website views per year

At $\mathrm{BMC}$, research is always in progress.

Learn more biomedcentral.com/submissions 